Jahrbuch Schweiz - Dritte Welt 1991

\title{
Die Schweiz und die Bretton-Woods-Institutionen
}

La Suisse et les institutions de Bretton Woods

\section{Pierre Languetin}

\section{OpenEdition}

\section{Journals}

Édition électronique

URL : http://journals.openedition.org/sjep/1225

DOI : $10.4000 /$ sjep.1225

ISSN : 1663-9677

\section{Éditeur}

Institut de hautes études internationales et du développement

\section{Édition imprimée}

Date de publication : 1 janvier 1991

Pagination : 171-181

ISSN : 1660-5926

\section{Référence électronique}

Pierre Languetin, « Die Schweiz und die Bretton-Woods-Institutionen», Schweizerisches Jahrbuch für Entwicklungspolitik [En ligne], 10 | 1991, mis en ligne le 14 avril 2013, consulté le 08 septembre 2020 URL : http://journals.openedition.org/sjep/1225 ; DOI : https://doi.org/10.4000/sjep.1225

Ce document a été généré automatiquement le 8 septembre 2020

(c) The Graduate Institute 


\section{Die Schweiz und die Bretton-Woods- Institutionen}

La Suisse et les institutions de Bretton Woods

Pierre Languetin

NOTE DE L'ÉDITEUR

Volltext auf Französisch in Annuaire suisse de politique de développement: „La Suisse et les institutions de Bretton Woods", http://aspd.revues.org/1377. 